\title{
META-ANALYSIS: EFFECT OF ULTRASOUND THERAPY TO REDUCE PAIN IN CARPAL TUNNEL SYNDROME CASES
}

\author{
Afifah Noer'), Setyo Sri Rahardjo²), Hanung Prasetya3) \\ ${ }^{1)}$ Masters Program in Public Health, Universitas Sebelas Maret \\ 2)Faculty of Medicine, Universitas Sebelas Maret \\ 3)Study Program of Acupunture, Health Polytechnics, Ministry of Health Surakarta
}

\begin{abstract}
Background: The carpal tunnel syndrome, caused by compression of the median nerve at the wrist, is considered the most common entrapment neuropathy. Ultrasound treatment may have the potential to induce various biophysical effects within tissue. It stimulates nerve regeneration and nerve conduction. Findings of an anti-inflammatory effect of such treatment support the concept that ultrasound treatment might facilitate recovery from nerve compression. This study aimed to investigate the effect of ultrasound therapy to reduce pain in carpal tunnel syndrome.

Subjects and Method: A systematic review was conducted using the PubMed, Science Direct, Google Scholar, and Springerlink databases, published from 2004 to 2021. The following search terms were used: ("ultrasonografi" OR "US") AND ("carpal tunnel syndrome" OR "CTS") AND ("randomized controlled trial”). The inclusion criteria were English full-text, randomized controlled trial, and reported Mean and Standard Deviation. The systematic review was carried out according to the PRISMA guidelines. Data analyses were performed using RevMan 5.3.

Results: 11 studies involved from United States, Taiwan, Iran, Switzerland, China, Spain, Turkey, Poland, and Pakistan. This study showed that ultrasound therapy reduces pain in patient with carpal tunnel syndrome ( $\mathrm{SMD}=-0.69 ; 95 \% \mathrm{CI}=-1.36$ to $-0.02 ; \mathrm{p}=0.040)$.

Conclusion: Ultrasound therapy reduces pain in patient with carpal tunnel syndrome.
\end{abstract}

Keywords: terapi ultrasonografi, carpal tunnel syndrome, meta-analisis

Correspondence:

Afifah Noer. Masters Program in Public Health, Universitas Sebelas Maret. Jl. Ir. Sutami 36A, Surakarta 57126, Central Java. Email: afifahnoero5@student.uns.ac.id. 